\title{
Effects of feeding supplemental organic iron to late gestation and early lactation dairy cows
}

\author{
W. P. Weiss, ${ }^{* 1}$ J. M. Pinos-Rodríguez, ${ }^{* 2}$ and M. T. Socha† \\ *Department of Animal Sciences, Ohio Agricultural Research and Development Center, The Ohio State University, Wooster 44691 \\ †Zinpro Corp., 10400 Viking Dr., Eden Prairie, MN 55344
}

\begin{abstract}
The objectives of this experiment were to determine the Fe status of cows in late gestation and early lactation and determine whether measures of Fe status and milk production were affected by feeding supplemental organic Fe. Starting 60 d before anticipated calving, cows and heifers were fed diets with 0 or $30 \mathrm{mg} / \mathrm{kg}$ of supplemental Fe (Availa-Fe, Zinpro Corp., Eden Prairie, MN). All animals changed to prefresh diets at $14 \mathrm{~d}$ before anticipated calving and then to lactation diets following calving; the Fe supplementation rates (0 or $30 \mathrm{mg} / \mathrm{kg}$ ) remained constant. The experiment ended at $63 \mathrm{~d}$ in milk. Hematocrit, hemoglobin, serum $\mathrm{Fe}$, unsaturated Fe binding capacity, and percentage Fe binding saturation were measured at the start of the experiment, $7 \mathrm{~d}$ before calving, $7 \mathrm{~d}$ after calving, and at $60 \mathrm{~d}$ in milk. Treatment did not affect any measure of Fe status and values did not change greatly over time. Milk production (averaged $41 \mathrm{~kg} / \mathrm{d}$ ), milk composition, and dry matter intake during early lactation (averaged $20.4 \mathrm{~kg} / \mathrm{d}$ ) were not affected by treatment. The somatic cell count of milk was reduced when cows were fed supplemental Fe (114,000 vs. 94,000 cells/mL). The limited response to supplemental Fe may have been because basal diets were adequate in $\mathrm{Fe}$ (ranged from 282 to $336 \mathrm{mg}$ of $\mathrm{Fe} / \mathrm{kg}$ of DM) even though most of the basal dietary Fe was provided by forages, which are generally considered poor sources of available Fe.
\end{abstract}

Key words: iron requirement, dairy cow, hemoglobin, iron binding capacity

\section{INTRODUCTION}

Over the past several decades, milk yield per cow has increased greatly with a concomitant increase in the

Received January 4, 2010.

Accepted January 24, 2010.

${ }^{1}$ Corresponding author: weiss.6@osu.edu

${ }^{2}$ Current address: Instituto de Investigación de Zonas Deserticas, Universidad Autónoma de San Luis Potosí, Altair No. 200, Fracc. del Llano, 78377 San Luis Potosí, SLP, Mexico. need for nutrients. Although Fe is a required nutrient for adult dairy cattle, essentially no research has been conducted evaluating its requirement in the last $50 \mathrm{yr}$. A possible reason for the lack of research in this area in dairy cows is that diets typically contain substantial concentrations of Fe. A major source of dietary Fe for dairy cows is forage. Forages, because of soil contamination, often contain more than $200 \mathrm{mg} / \mathrm{kg}$ of Fe, which presumably should be adequate to meet or exceed a cow's requirement for Fe (Underwood and Suttle, 1999). Soil $\mathrm{Fe}$, however, can have very low bioavailability (Hansen and Spears, 2009). Another possible reason for the lack of research evaluating $\mathrm{Fe}$ requirements is the known negative effects of feeding excess Fe. Diets that contain $\geq 250 \mathrm{mg}$ of supplemental Fe/ $\mathrm{kg}$ of DM from Fe sulfate (a good source of bioavailable Fe; van Ravenswaay et al., 2001) can reduce the $\mathrm{Cu}$ status of cattle, increase oxidative stress, and have detrimental effects on cow health, production, intake, and fiber digestion (Boyne and Arthur, 1986; Barraza et al., 1991; Harrison et al., 1992; Campbell and Miller, 1998; McCaughey et al., 2005).

Even though new data were lacking, the National Research Council (NRC, 1989, 2001) requirements for Fe for lactating dairy cows decreased substantially from $1989(50 \mathrm{mg} / \mathrm{kg})$ to 2001 (approximately $20 \mathrm{mg} / \mathrm{kg}$ ). The NRC (2001) Fe requirement was calculated using data from 6-wk-old calves and pregnant ewes. Because Fe absorption is strongly influenced by body iron status (Ammerman et al., 1967), nonlactating dairy cows and other species of animals may not be accurate models of a high-producing lactating dairy cow. Indirect evidence suggests that limited amounts of supplemental Fe may be beneficial to cows. Supplemental iron $(<30 \mathrm{mg} / \mathrm{kg})$ improved in vitro cellulose digestion (Martinez and Church, 1970). An association between low hemoglobin concentrations and low milk yields has been shown in dairy goats (Atroshi et al., 1986), and hemoglobin is correlated with body iron stores of cows (Miyata and Furugouri, 1987). Based on some but not all measures, the Fe status of dairy cows may decrease during late gestation (Furugouri et al., 1982). For those measures of status that did decrease, some decreased a few weeks 
before parturition, but others declined throughout the dry period. Because of the life span of mammalian red cells ( 120 d; Brace et al., 2000), reduced Fe status during this period may carry over several months into the lactation period.

We hypothesized that because of fetal growth, increased maternal blood volume, and low DMI (relative to that in lactating cows), Fe status may be reduced in late gestation dairy cows and that supplementing a small quantity (30 $\mathrm{mg} \mathrm{Fe} / \mathrm{kg}$ of diet DM) of bioavailable Fe would improve measures of Fe status. Furthermore, improved Fe status in late gestation should result in increased milk production in early lactation. The objective of this experiment was to determine the effects of feeding supplemental Fe to dairy cows in late gestation through early lactation on measures of Fe status and milk production and composition.

\section{MATERIALS AND METHODS}

\section{Cows and Diets}

All procedures involving animals in this experiment were approved by the Agricultural Animal Care and Use Committee of The Ohio State University. Holstein heifers $(\mathrm{n}=12)$ and cows $(\mathrm{n}=42)$ were grouped by parity (heifers and cows) and anticipated calving date into 27 blocks of 2 animals. Within block, each animal was assigned randomly to the control treatment (no supplemental iron) or $\mathrm{Fe}$ treatment $(30 \mathrm{mg} / \mathrm{kg}$ additional $\mathrm{Fe}$ provided by an iron-amino acid complex, Availa-Fe, Zinpro Corp., Eden Prairie, MN). Based on typical DMI and typical feedstuffs, diets with between 15 and $25 \mathrm{mg} / \mathrm{kg}$ of total Fe should meet the Fe requirement of dry, transition, and early lactation dairy cows (NRC, 2001). High supplementation rates of Fe (approximately 100 to $600 \mathrm{mg} / \mathrm{kg}$ ) can be detrimental (Harrison et al., 1992) to rumen fermentation and cow health (Campbell and Miller, 1998). The supplementation rate of $30 \mathrm{mg} / \mathrm{kg}$ was chosen because nutritionists often do not consider the trace minerals supplied by the basal diet (i.e., supplemental trace minerals are added to equal NRC recommendations for total trace minerals) and it was well below rates shown to have adverse effects.

Animals started the experiment $60 \mathrm{~d}$ before anticipated calving and the experiment ended at 63 DIM. During the last $60 \mathrm{~d}$ of gestation, animals were grouphoused within treatment in adjacent, similar pens (1 pen per treatment). Pen DMI was measured daily (10.8 and $10.6 \mathrm{~kg} / \mathrm{d}$ for control and supplemented pens). Diets were fed as TMR once daily and were identical except for Fe supplementation (Tables 1 and 2). The amount of TMR offered was adjusted daily to maintain $<2 \%$ feed refusals (as-fed basis). At $14 \mathrm{~d}$ before anticipated calving, cows were moved to individual box stalls and fed a transition diet (Table 1) but remained on the same Fe supplementation treatment. Cows were fed once daily and enough was offered to provide for approximately $5 \%$ feed refusals (as-fed basis). Feed offered and feed refused was measured daily. After calving, cows were moved to tie stalls and fed a lactation diet (Table 1) but remained on the same Fe treatment to which they were first assigned. Cows were fed once daily to allow approximately 10\% feed refusals (as-fed basis). During the lactation phase, cows were milked twice daily with milk weights recorded electronically. After calving, a.m. and p.m. milk samples were taken weekly (after 3 DIM) from each cow until 63 DIM and analyzed for milk fat, protein, lactose (B2000 Infrared Analyzer, Bentley Instruments, Chaska, MN) and MUN (Skalar SAN Plus segmented flow analyzer, Skalar Inc., Norcross, GA) by DHI Cooperative Inc. (Columbus, OH). Cows were weighed at the start of the experiment $(60 \mathrm{~d}$ before anticipated calving), $14 \mathrm{~d}$ before anticipated calving, 3 DIM, and 63 DIM. Body condition $(1=$ emaciated; 5 = obese) was evaluated at 3 and 63 DIM by 2 independent scorers.

\section{Sampling and Analyses}

Blood samples were taken from the tail vein at $60 \mathrm{~d}$ before anticipated calving (before treatments were imposed), $7 \mathrm{~d}$ before anticipated calving, 7 DIM, and 63 DIM. One sample (approximately $7 \mathrm{~mL}$ ) was allowed to clot and serum was harvested; one sample $(7 \mathrm{~mL})$ was taken into tubes containing heparin. The heparinized whole blood was analyzed the same day for hematocrit [microhematocrit tubes centrifuged at 13,000 $\times g$ for 7 min in an IEC Microhematocrit Centrifuge (Thermo Fisher Scientific Inc., Waltham, MA) and read on an IEC Microcapillary Reader] and hemoglobin (Hemoglobin Reagent cat. no. 0320-650, standards cat. no. 0325006, and tri-level controls cat. no. 0330-302; Stanbio Laboratory, Boerne, TX). The serum was assayed for serum Fe and unsaturated Fe-binding capacity using commercial kits (Iron and Total Iron Binding Capacity, cat. no. 0370-110, Stanbio Laboratory), except that all volumes were reduced by a factor of 10 and tests were performed in 96-well microplates and read on a microplate reader (Bio-Tek Instruments Inc., Winooski, VT). Total Fe binding capacity was calculated as unsaturated Fe binding capacity - serum Fe. Percentage binding saturation was calculated as (serum $\mathrm{Fe} /$ total Fe binding capacity) $\times 100$.

All forages were sampled weekly and composited by month. Weekly silage samples were analyzed for DM $\left(100^{\circ} \mathrm{C}\right.$ oven for $\left.24 \mathrm{~h}\right)$ to adjust as-fed amounts. Con- 
Table 1. Ingredient composition (\% of DM) of control diets fed during the experiment ${ }^{1}$

\begin{tabular}{|c|c|c|c|}
\hline Item & Dry cow & Prefresh & Lactation \\
\hline Mature grass hay & 50.0 & 25.0 & - \\
\hline Mostly grass silage & 22.0 & - & - \\
\hline Corn silage & 17.0 & 20.3 & 25.0 \\
\hline Alfalfa silage & - & 15.4 & 30.0 \\
\hline Corn grain, ground & 1.25 & 15.90 & 16.7 \\
\hline Soybean meal, $44 \% \mathrm{CP}$ & 5.23 & 9.60 & 3.92 \\
\hline Soybean hulls & 2.82 & 11.30 & 3.20 \\
\hline Treated soybean meal ${ }^{2}$ & - & - & 5.85 \\
\hline Distillers grains with solubles & - & - & 4.32 \\
\hline Wheat middlings & - & - & 7.07 \\
\hline Fat supplement $^{3}$ & - & - & 1.76 \\
\hline Limestone & 0.08 & 0.29 & 0.78 \\
\hline Mg oxide/Mg sulfate $(50: 50)$ & 0.28 & 0.31 & - \\
\hline Iodized salt & 0.17 & 0.43 & 0.39 \\
\hline Sodium bicarbonate & - & - & 0.29 \\
\hline Organic trace mineral $\operatorname{mix}^{4}$ & 0.09 & 0.09 & 0.07 \\
\hline Selenium/vitamin premix ${ }^{5}$ & 1.08 & 1.38 & 0.65 \\
\hline
\end{tabular}

${ }^{1}$ Treatment diets were identical except they contained $0.003 \%$ organic $\mathrm{Fe}(10 \% \mathrm{Fe}$, Availa-Fe 100, Zinpro Corp., Eden Prairie, MN) in place of corn meal.

${ }^{2}$ Nonenzymatically browned soybean meal (Borregaard LignoTech, Rothschild, WI).

${ }^{3}$ Energy Booster 100 (Milk Specialties Global, Carpentersville, IL).

${ }^{4} 4$-Plex (Zinpro Corp.); contained $0.90 \% \mathrm{Cu}$ from $\mathrm{Cu}$ lysine, $0.18 \% \mathrm{Co}$ from Co glucoheptonate, $1.43 \% \mathrm{Mn}$ from Mn methionine, and $2.58 \%$ zinc from $\mathrm{Zn}$ methionine.

${ }^{5}$ Provided $20 \mathrm{mg}$ of biotin, 90 and $25 \mathrm{kIU}$ of vitamins $\mathrm{A}$ and $\mathrm{D}, 500$ (lactating) or 1,000 (dry/prefresh) IU of vitamin E daily, and $0.3 \mathrm{mg}$ of $\mathrm{Se} / \mathrm{kg}$ of diet DM (from sodium selenate).

centrates were sampled every $2 \mathrm{wk}$ and composited by month. Feed refusals by lactating cows were sampled every $2 \mathrm{wk}$ and analyzed for $\mathrm{DM}\left(100^{\circ} \mathrm{C}\right.$ for $\left.24 \mathrm{~h}\right)$ for DMI calculations. Composite feed samples were dried $\left(55^{\circ} \mathrm{C}\right.$ for $\left.48 \mathrm{~h}\right)$ and then ground through a $1-\mathrm{mm}$ screen (Wiley mill, Arthur A. Thomas, Philadelphia, PA). Ground samples were analyzed for DM $\left(100^{\circ} \mathrm{C}\right.$ oven for $24 \mathrm{~h}$ ), NDF (Ankom ${ }^{200}$ Fiber Analyzer, Ankom Technology, Fairport, NY) with sodium sulfite and amylase (\#FFA, Ankom Technology), CP (Kjeldahl N × 6.25), and ash (AOAC, 2000). For specific mineral assays, ground forage samples were dry-ashed (AOAC, 2000) and concentrate feed samples were digested with perchloric acid (AOAC, 2000); inductively coupled plasma emission spectroscopy was used to quantify mineral concentrations. The drinking water for the cows was sampled monthly from 2 sites at the dairy center and analyzed for minerals $(\mathrm{n}=10$ total samples). All samples had no detectable concentrations of Fe (detection limit $0.002 \mathrm{mg} / \mathrm{L})$.

\section{Statistical Analysis}

Of the 54 animals that started this experiment, 3 animals (all on the Fe treatment) did not complete the experiment. One primiparous cow developed nonresponsive ketosis after calving and was culled, one multiparous cow was injured after falling and was euthanized, and one multiparous cow developed an unidentified systemic infection and was euthanized. All data from those animals were excluded from statistical analysis. Pens were not replicated; therefore, data collected during the pen feeding phase cannot be statistically analyzed. Milk SCC (cells/mL) was transformed to $\log _{10}$ to normalize the data before statistical analysis.

The average duration of the prefresh period was 13.5 $\mathrm{d}(\mathrm{SD}=3.6)$, which corresponds to the targeted 14-d prefresh period. All cows were in box stalls for at least $7 \mathrm{~d}$ before actual calving; therefore, DMI data from the last $7 \mathrm{~d}$ of gestation were averaged within cow and analyzed statistically using PROC MIXED (SAS Institute, 2004) with a model that included block (26 df, random), treatment (1 df, fixed), and error (23 df). Average daily change in BW during late gestation (difference between 60 and $14 \mathrm{~d}$ before anticipated calving) and during early lactation (between 3 and 63 DIM), and change in BCS in lactation (3 to 63 DIM) were analyzed using that same model.

Table 2. Nutrient composition of diets (DM basis)

\begin{tabular}{|c|c|c|c|c|c|c|}
\hline \multirow[b]{2}{*}{ Item } & \multicolumn{2}{|c|}{ Dry cow } & \multicolumn{2}{|c|}{ Prefresh } & \multicolumn{2}{|c|}{ Lactation } \\
\hline & $-\mathrm{Fe}$ & $+\mathrm{Fe}$ & $-\mathrm{Fe}$ & $+\mathrm{Fe}$ & $-\mathrm{Fe}$ & $+\mathrm{Fe}$ \\
\hline DM, \% & 67.7 & 67.6 & 71.7 & 71.8 & 65.0 & 65.0 \\
\hline $\mathrm{CP}, \%$ & 13.0 & 13.0 & 14.6 & 14.7 & 15.9 & 16.3 \\
\hline NDF, $\%$ & 52.0 & 51.9 & 42.4 & 42.3 & 35.6 & 35.4 \\
\hline Ash, $\%$ & 7.6 & 7.6 & 7.3 & 7.2 & 6.6 & 6.5 \\
\hline $\mathrm{Ca}, \%$ & 0.67 & 0.65 & 0.87 & 0.85 & 0.96 & 0.88 \\
\hline $\mathrm{P}, \%$ & 0.29 & 0.29 & 0.30 & 0.30 & 0.36 & 0.36 \\
\hline $\mathrm{Mg}, \%$ & 0.29 & 0.28 & 0.32 & 0.31 & 0.21 & 0.22 \\
\hline $\mathrm{K}, \%$ & 2.03 & 2.04 & 1.61 & 1.62 & 1.41 & 1.41 \\
\hline $\mathrm{Na}, \%$ & 0.09 & 0.09 & 0.19 & 0.19 & 0.27 & 0.26 \\
\hline $\mathrm{Cu}, \mathrm{mg} / \mathrm{kg}$ & 15 & 14 & 16 & 15 & 13 & 12 \\
\hline $\mathrm{Mn}, \mathrm{mg} / \mathrm{kg}$ & 104 & 108 & 74 & 78 & 66 & 73 \\
\hline $\mathrm{Zn}, \mathrm{mg} / \mathrm{kg}$ & 69 & 78 & 75 & 84 & 76 & 73 \\
\hline
\end{tabular}


Table 3. Concentrations of iron in major diet ingredients and $\mathrm{TMR}^{1}$

\begin{tabular}{lcc}
\hline Item & Fe, $\mathrm{mg} / \mathrm{kg}$ of DM & $\mathrm{SD}$ \\
\hline Ingredient (diet) & & 51 \\
Grass hay (dry cows) & 137 & 180 \\
Grass hay (prefresh cows) & 310 & 513 \\
Grass silage (dry cows) & 618 & 139 \\
Corn silage (all cows) & 429 & 114 \\
Alfalfa silage (prefresh and lactating) & 300 & 56 \\
Dry cow control concentrate mix & 432 & 60 \\
Dry cow Fe concentrate mix & 672 & 11 \\
Lactating cow control concentrate mix & 189 & 19 \\
Lactating cow Fe concentrate mix & 241 & - \\
Calculated concentrations of total diets & 313 & - \\
Dry cow, control & 340 & - \\
Dry cow, Fe treatment & 336 & - \\
Prefresh, control & 362 & - \\
Prefresh, Fe treatment & 282 & - \\
Lactating cow, control & 306 & \\
Lactating cow, Fe treatment & & \\
1ㄹefresh cows (last 14 d of gestation) did not have a separate concentrate mix. They were fed a mixture of dry \\
and lactating cow concentrate mixes.
\end{tabular}

Milk and DMI data (3 to 63 DIM) were averaged into six 10-d periods within cow and analyzed using PROC MIXED with block (26 df, random), treatment (1 df, fixed), period ( $5 \mathrm{df}$, repeated, fixed), treatment by period interaction ( $5 \mathrm{df}$, fixed) and error. Milk composition data were analyzed with the same model except that samples were taken weekly resulting in 8 periods rather than 6 . Blood data were analyzed within each day using the same model as used for prefresh DMI and also across all days ( $-7,7$, and 63 DIM) using the repeated measures model described above except that period had only $2 \mathrm{df}$.

\section{RESULTS AND DISCUSSION}

\section{Dietary Fe Concentrations}

The targeted supplementation rate for Fe was $30 \mathrm{mg} /$ $\mathrm{kg}$; based on assayed values (Table 3), the supplemented diets had 27, 26, and $24 \mathrm{mg} / \mathrm{kg}$ more Fe than control diets during the dry period, prefresh period, and lactation period, respectively. Calculated dietary concentrations of $\mathrm{Fe}$ (based on assayed values of ingredients) ranged from 282 to $362 \mathrm{mg} / \mathrm{kg}$, values that are more than 10 times higher than the NRC (2001) requirement for Fe. The supplemental Fe contributed approximately $8 \%$ of the total dietary Fe across all phases of this experiment. During the gestation phase, forage provided 65 and $60 \%$ of the total dietary Fe for the control and supplemented groups; during the lactation phase, forages provided 70 and $64 \%$ of the dietary Fe (Table 3). Most of the forages had more than $300 \mathrm{mg} / \mathrm{kg}$ of $\mathrm{Fe}$ and concentrations were highly variable (CV for forages ranged from 37 to $84 \%$ ). The Fe concentrations in the concentrates were much less variable (CV ranged from 6 to 13\%). Coefficients of variation for forages often exceed 100\% [feed composition databases from Dairyland Laboratories Inc. (www.dairylandlabs.com) and Dairy One Cooperative Inc. (www.dairyone.com)]. The primary reason silage and hays often have high and variable concentrations of $\mathrm{Fe}$ is soil contamination. The Fe in soil is considered to have poor bioavailability because of the presence of chelating agents (Hansen and Spears, 2009) and because the Fe is mostly in the ferric form, which is generally much less bioavailable, at least in nonruminants, than ferrous or heme iron (Miret et al., 2003). The availability of soil Fe, however, might be increased by silage fermentation. Using various in vitro and chemical measurements that may be related to bioavailability, Hansen and Spears (2009) reported that soil Fe added to corn plants and then fermented for $90 \mathrm{~d}$ was 3 to 12 times more bioaccessible than soil Fe added to corn silage and assayed immediately. Nevertheless, even following fermentation, soil Fe was $<2 \%$ bioaccessible based on dialyzable Fe concentrations. The diets in this study contained substantial concentrations of $\mathrm{Fe}$, but because much of it was provided by forage (and likely soil contamination) bioavailability may have been limited.

\section{Blood Measures}

We hypothesized that the most likely response to supplemental Fe would occur during late gestation and early lactation; therefore, this type of cow was the experimental unit. Supply of dietary Fe is relatively low during this period because of low DMI (relative to a high-producing dairy cow) but the need for Fe is high 


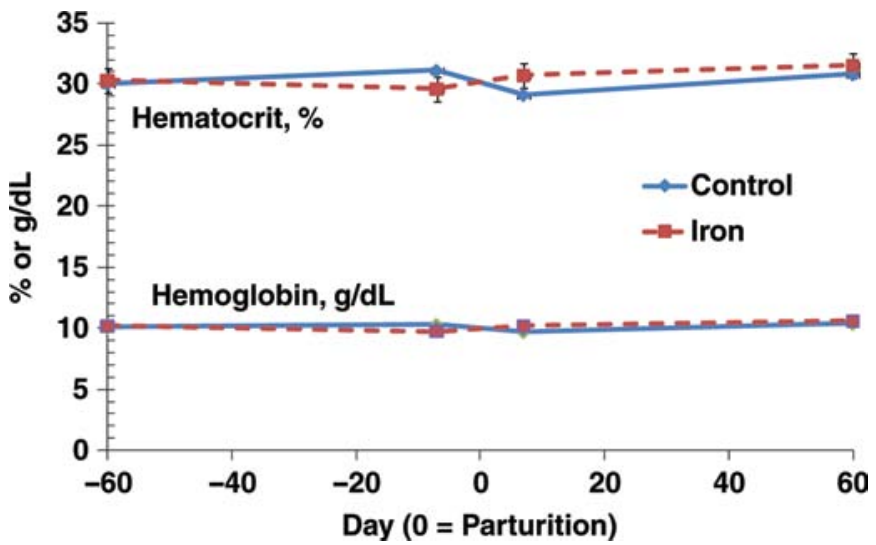

Figure 1. Effect of feeding diets with 0 or $30 \mathrm{mg} / \mathrm{kg}$ of supplemental Fe to late gestation and early lactation dairy cows on hematocrit and hemoglobin concentrations. Treatment did not affect these measures, but time $(P<0.05)$ and the treatment $\times$ time interaction $(P$ $<0.05)$ affected both measurements $(P<0.05)$. When error bars are not visible, the $\mathrm{SE}$ is smaller than the size of the symbol. Color version available in the online PDF.

because of fetus and conceptus growth and increased maternal blood volume. During the last $80 \mathrm{~d}$ of gestation, the accretion rate of $\mathrm{Fe}$ in the conceptus (fetus, fluids, fetal membranes, and uterine tissue) was $18 \mathrm{mg} / \mathrm{d}$ for Holstein cows (House and Bell, 1993). In addition to fetal accretion, maternal blood volume increases during gestation (Reynolds, 1953), which may require as much as $10 \mathrm{mg} / \mathrm{d}$ of $\mathrm{Fe}$ for maternal hematopoiesis (assumed Fe concentration of erythrocytes $=20 \mathrm{mM})$. The total Fe needed by cows in late gestation (approximately 28 $\mathrm{mg} / \mathrm{d}$ ) is equivalent to the daily Fe secreted in milk by a cow producing $28 \mathrm{~kg}$ of milk/d, but the lactating cow would be expected to consume 8 to $10 \mathrm{~kg}$ more DM/d than a late gestation cow.

Based on several indicators of Fe status (Figures 1, 2, 3 , and 4 ), there was no evidence to suggest reduced status from $60 \mathrm{~d}$ prepartum through $60 \mathrm{~d}$ postpartum, and values were within normal reference ranges (Underwood and Suttle, 1999). Time (samples collected at $-60,-7$, 7 , and 60 DIM) did not affect $(P>0.3)$ Fe binding capacity measurements but did affect $(P<0.05)$ serum Fe, hemoglobin, and hematocrit. Differences, however, were minor across time points (Figures 1 and 2) and are likely not biologically important. Supplemental Fe did not affect hematocrit, hemoglobin, serum Fe, Fe binding capacity saturation, and percentage saturation $(P>0.4$ for all measurements), probably because no indication of reduced status was observed in control cows. Interactions between time and treatment were observed $(P<0.05)$ for hematocrit and hemoglobin as illustrated by the crossing lines in Figure 1 that occur between -7 and 7 DIM. However, the numerical changes that occurred were very small and probably not biologically important.

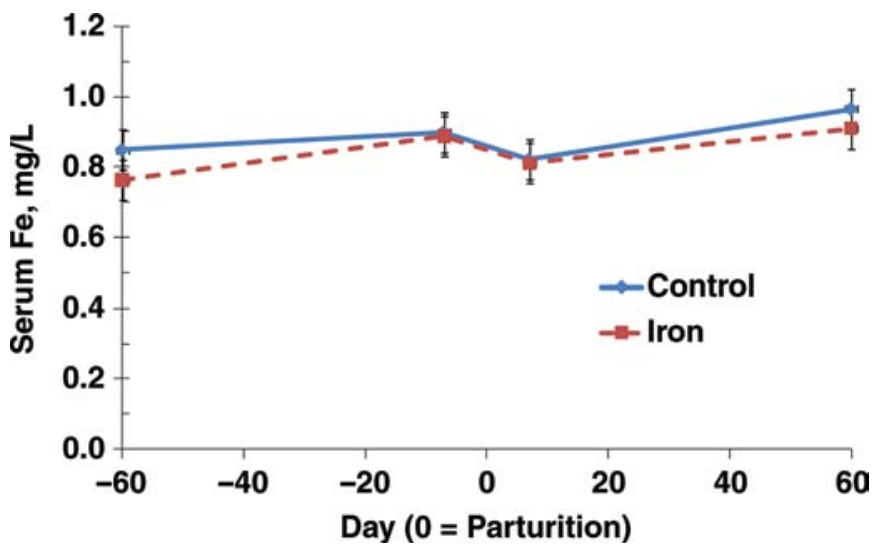

Figure 2. Effect of feeding diets with 0 or $30 \mathrm{mg} / \mathrm{kg}$ of supplemental $\mathrm{Fe}$ to late gestation and early lactation dairy cows on serum $\mathrm{Fe}$ concentrations. No treatment or treatment by time interactions were observed $(P>0.2)$, but values were affected by time $(P<0.05)$. Color version available in the online PDF.

Furugouri et al. (1982), in a limited study (10 Holstein cows), reported that serum $\mathrm{Fe}$ and $\mathrm{Fe}$ binding measurements decreased during the peripartum period, reaching their nadir at or shortly after parturition. Hematocrit and hemoglobin concentrations also decreased during this period but reached their nadir 2 to $3 \mathrm{wk}$ after parturition. Diets and milk production were not reported in that paper. Miltenburg et al. (1991) also reported that serum Fe and some Fe binding measures decreased at calving in crossbred Friesian cattle (diets and milk yields not reported). The reasons why measures of Fe status in this study did not change over late gestation and early lactation when earlier studies found decreased status around calving cannot be elucidated

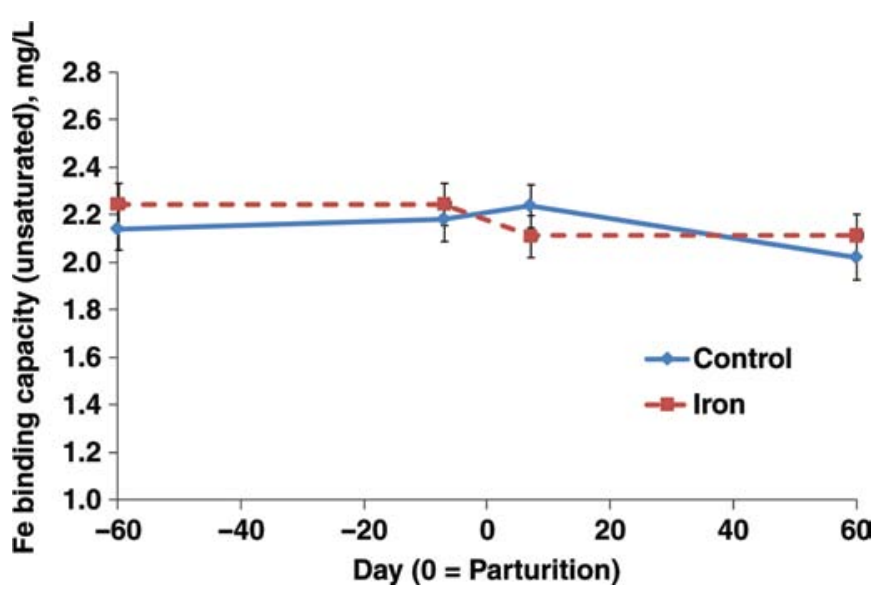

Figure 3. Effect of feeding diets with 0 or $30 \mathrm{mg} / \mathrm{kg}$ of supplemental Fe to late gestation and early lactation dairy cows on serum unsaturated Fe binding capacity. No treatment, time, or treatment $x$ time interaction effects were observed $(P>0.2)$. Color version available in the online PDF. 
but differences in diet composition and DMI might be involved.

Studies examining the effects of supplemental Fe on measures of $\mathrm{Fe}$ status in adult cattle are lacking. In calves that are deficient in Fe, supplemental Fe can increase hemoglobin, hematocrit, and serum Fe (Reece et al., 1985; Kume and Tanabe, 1994); in Fe-deficient pigs, supplemental Fe reduces unsaturated Fe binding capacity by increasing the percentage saturation (Furugouri, 1972). However, in calves that were Fe adequate, feeding additional $\mathrm{Fe}$ (even very high amounts of $\mathrm{Fe}$ ) did not affect these measures (McGuire et al., 1985). The lack of substantial treatment effects on blood measures of $\mathrm{Fe}$ status suggests that cows in this study were adequate in $\mathrm{Fe}$ and additional $\mathrm{Fe}$ was unnecessary.

\section{Production Data}

Body weights during the experiment were not affected by treatment (Table 4). On average, BW increased during the late gestation period $(0.25 \mathrm{~kg} / \mathrm{d} ; \mathrm{SE}=0.14$; $P>0.9$, data not shown) and decreased during early lactation $(-0.71 \mathrm{~kg} / \mathrm{d} ; \mathrm{SE}=0.16 ; P>0.5)$. Body condition score during early lactation was not affected by treatment $(P>0.4)$. The BCS averaged 3.3 at 3 DIM and 2.9 at 60 DIM (SE for both time points $=0.1$ ).

Intake during the $7 \mathrm{~d}$ before calving, milk production, milk composition, and DMI by cows in early lactation was not affected by feeding supplemental $\mathrm{Fe}$ (Table 4, Figure 5). If supplemental Fe had increased milk production, the most likely mode of action would be increased oxygen carrying capacity of the blood or improved health (e.g., less mastitis) via reduced oxidative stress because of enhanced antioxidant status. Published data with lactating dairy cows is lacking but anemic dairy calves grow slower than healthy calves,

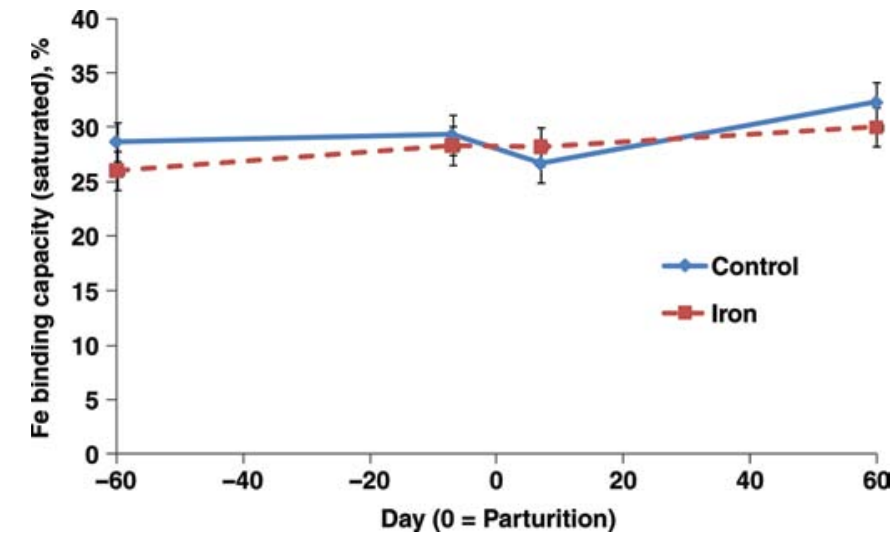

Figure 4. Effect of feeding diets with 0 or $30 \mathrm{mg} / \mathrm{kg}$ of supplemental Fe to late gestation and early lactation dairy cows on percentage of Fe binding capacity that is saturated. No treatment, time, or treatment $\times$ time interaction effects were observed $(P>0.2)$. Color version available in the online PDF.

and supplemental dietary Fe can increase growth rate when given to Fe-deficient calves (Thomas et al., 1954). The lack of treatment responses for hemoglobin and hematocrit suggests that the oxygen-carrying capacity of the blood was not altered by treatment and was not limiting in the control cows. Other dietary situations including lower basal concentrations of $\mathrm{Fe}$ and the presence of $\mathrm{Fe}$ antagonists might influence $\mathrm{Fe}$ status and might change the response to supplemental Fe. For example, in a recent study with beef cattle, supplementation with $10 \mathrm{mg} / \mathrm{kg}$ of $\mathrm{Cu}$ (basal diet was $7 \mathrm{mg} / \mathrm{kg}$ of $\mathrm{Cu}$ ) significantly reduced Fe concentrations in plasma and liver (Hansen et al., 2009) although concentrations were still in the normal range.

Iron supplementation can affect immune function and oxidative balance in animals. Beef cattle fed diets with high concentrations of supplemental Fe (500 mg/

Table 4. Production data for 3 to $63 \mathrm{~d}$ in milk for cows fed diets with 0 or $30 \mathrm{mg} / \mathrm{kg}$ of supplemental Fe ${ }^{1}$

\begin{tabular}{lcccc}
\hline Item & Control & Fe & SEM & $P<$ \\
\hline BW at dry-off, kg & 710 & 690 & 15.0 & 0.76 \\
BW at 14 d before calving, kg & 722 & 703 & 14.7 & 0.36 \\
BW at 3 DIM, kg & 669 & 647 & 12.7 & 0.24 \\
BW at 60 DIM, kg & 624 & 611 & 12.0 & 0.45 \\
Prepartum DMI, kg/d & 11.8 & 11.3 & 0.39 & 0.19 \\
Postpartum DMI, kg/d & 20.7 & 20.1 & 0.51 & 0.24 \\
Milk, kg/d & 41.7 & 42.0 & 1.25 & 0.84 \\
Milk/DMI & 2.04 & 2.11 & 0.039 & 0.19 \\
Milk fat, \% & 4.80 & 4.60 & 0.12 & 0.19 \\
Milk protein, \% & 2.83 & 2.82 & 0.037 & 0.8 \\
Milk fat, kg/d & 2.01 & 1.95 & 0.07 & 0.5 \\
Milk protein, kg/d & 1.18 & 1.19 & 0.03 & 0.7 \\
MUN, mg/dL & 9.19 & 8.95 & 0.24 & 0.35 \\
SCC, $\log _{10}$ (cells/mL) & 4.62 & 4.37 & 0.11 & 0.04 \\
\hline
\end{tabular}

${ }^{1}$ The time (six 10-d periods) by treatment interaction was not significant $(P>0.3)$ for any postpartum measurement (time was not included in statistical analysis for BW).

${ }^{2} \mathrm{DMI}$ during the last $7 \mathrm{~d}$ of gestation. 


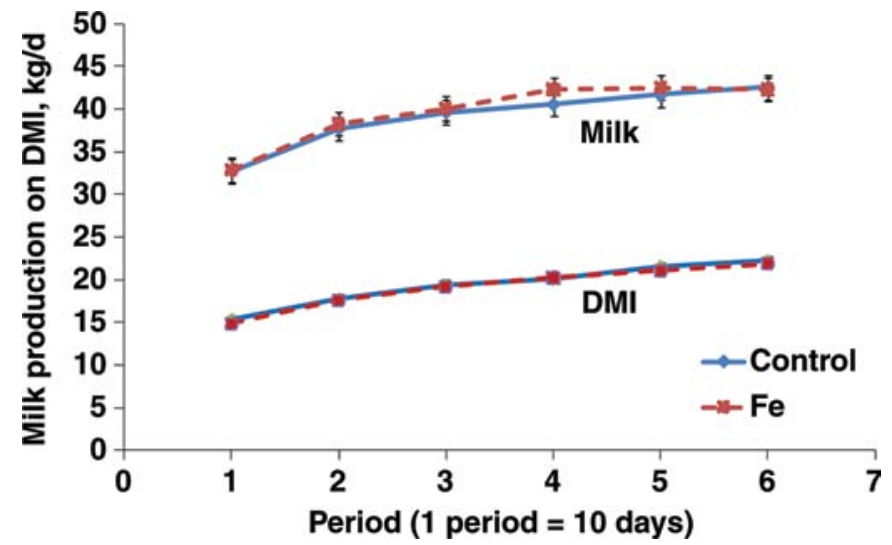

Figure 5. Effect of feeding diets with 0 or $30 \mathrm{mg} / \mathrm{kg}$ of supplemental Fe to late gestation and early lactation dairy cows on milk production and DMI. Period 1 started at 3 DIM. No treatment or treatment $\times$ time interactions were observed $(P>0.2)$. Color version available in the online PDF.

$\mathrm{kg}$ from Fe sulfate) had reduced neutrophil function (phagocytosis and killing ability), which was ascribed to reduced $\mathrm{Cu}$ status (Boyne and Arthur, 1986). Other studies have shown no negative effects of high dietary Fe (Niederman et al., 1994; Gengelbach et al., 1997). Interestingly, in one study (Gengelbach et al., 1997), neutrophil kill was substantially higher (although not statistically higher) when cattle were fed $600 \mathrm{mg} / \mathrm{kg}$ of supplemental Fe (from Fe sulfate) compared with cattle not fed supplemental Fe. Iron-deficient rats had evidence of increased oxidative damage compared with rats fed Fe-adequate diets (Rao and Jagadeesan, 1996). One presumed mode of action for that response is via catalase, an Fe-containing enzyme that catalyzes the reaction that converts hydrogen peroxide to water. However, in the Rao and Jagadeesan (1996) study, hepatic catalase activity was not different between Fe-deficient and Fe-adequate rats although several measures confirmed increased oxidative stress with Fe deficiency. Based on measures of Fe status in our study, control and supplemented cows were probably in similar Fe status suggesting that oxidative stress did not differ between groups. However, cows fed supplemental Fe had lower $\log _{10}$ SCC $(P<0.05)$ than control cows, and increased mastitis is related to oxidative stress and antioxidant status (Weiss and Spears, 2005). The treatment effect on SCC, however, must be considered carefully. Arithmetic mean SCC was 114,000 and 94,000 cells/mL for control and treatment, respectively, and the biological and economic significance of this difference is probably limited. Additional research (preferably with cows with higher SCC) is needed to verify this finding.
This experiment ended at 63 DIM and the voluntary waiting period before breeding for our herd is 60 d. Therefore, this study was not designed to evaluate the effects of $\mathrm{Fe}$ on reproduction measures. After the experiment concluded, cows on this protocol may have been culled for various reasons or would have been assigned to other experiments. Retrospective analysis of reproductive records were available on 19 (control) and 18 (Fe-supplemented) animals. Average days open were 87 and 90, and services per conception were 1.68 and 1.78 for control and Fe treatment. The data are inadequate to reach a valid conclusion on the effects of Fe on reproduction, but there is also no indication that it had any effect.

\section{CONCLUSIONS}

Adding $30 \mathrm{mg} / \mathrm{kg}$ of supplemental Fe from a Feamino acid complex to diets fed to dry cows, transition cows, and early lactation cows did not affect measures of Fe status and did not affect milk production and milk composition. Iron status did not change appreciably during the dry period and peripartum period and control cows appeared to be in adequate Fe status. Control diets contained between 282 (lactation) and 336 $\mathrm{mg} / \mathrm{kg}$ of $\mathrm{Fe}$ (prefresh), which greatly exceeded NRC recommendations for $\mathrm{Fe}$ (approximately $20 \mathrm{mg} / \mathrm{kg}$ of diet DM). However, much of the dietary Fe was provided from forages that were likely contaminated with soil. Supplemental Fe reduced SCC but whether the difference was economically or biologically important is unclear. Overall, control cows appeared adequate in $\mathrm{Fe}$ and cows generally did not respond to additional Fe.

\section{ACKNOWLEDGMENTS}

Salaries and research support was provided by state and federal funds appropriated to the Ohio Agricultural Research and Development Center, The Ohio State University. Additional support was provided by Zinpro Corp. (Eden Prairie, MN).

\section{REFERENCES}

Ammerman, C. B., J. M. Wing, B. G. Dunavant, W. K. Robertson, J. P. Feaster, and L. R. Arrington. 1967. Utilization of inorganic iron by ruminants as influenced by form of iron and iron status of the animal. J. Anim. Sci. 26:404-410.

Association of Official Analytical Chemists. 2000. Official Methods of Analysis. Vol. 1 and 2. 17th ed. AOAC International, Gaithersburg, MD.

Atroshi, F., S. Sankari, and U. B. Lindström. 1986. Somatic cell count and milk yield in relation to hemoglobin concentration in Finnish dairy goats. Vet. Res. Commun. 10:57-63. 
Barraza, M. L., C. E. Coppock, K. N. Brooks, D. L. Wilks, R. G Saunders, and G. W. Latimer Jr. 1991. Iron sulfate and feed pelleting to detoxify free gossypol in cottonseed diets for dairy cattle. J. Dairy Sci. 74:3457-3467.

Boyne, R., and J. R. Arthur. 1986. Effects of molybdenum or iron induced copper deficiency on the viability and function of neutrophils from cattle. Res. Vet. Sci. 41:417-419.

Brace, R. A., C. Langendörfer, T. B. Song, and D. M. Mock. 2000. Red blood cell life span in the ovine fetus. Am. J. Physiol. Regul. Integr. Comp. Physiol. 279:R1196-R1204.

Campbell, M. H., and J. K. Miller. 1998. Effect of supplemental dietary vitamin $\mathrm{E}$ and zinc on reproductive performance of dairy cows and heifers fed excess iron. J. Dairy Sci. 81:2693-2699.

Furugouri, K. 1972. Plasma iron and total iron-binding capacity in piglets in anemia and iron administration. J. Anim. Sci. 34:421426.

Furugouri, K., Y. Miyata, and K. Shijimaya. 1982. Ferritin in blood serum of dairy cows. J. Dairy Sci. 65:1529-1534.

Gengelbach, G. P., J. D. Ward, J. W. Spears, and T. T. Brown Jr.. 1997. Effects of copper deficiency and copper deficiency coupled with high dietary iron or molybdenum on phagocytic cell function and response of calves to a respiratory disease challenge. J. Anim. Sci. $75: 1112-1118$

Hansen, S. L., and J. W. Spears. 2009. Bioaccessibility of iron from soil is increased by silage fermentation. J. Dairy Sci. 92:2896-2905.

Hansen, S. L., N. Trakooljul, H.-C. S. Liu, J. A. Hicks, M. S. Ashwell, and J. W. Spears. 2010. Proteins involved in iron metabolism in beef cattle are affected by copper deficiency in combination with high dietary manganese, but not by copper deficiency alone. J. Anim. Sci. 88:275-283.

Harrison, G. A., K. A. Dawson, and R. W. Hemken. 1992. Effects of high iron and sulfate ion concentrations on dry matter digestion and volatile fatty acid production by ruminal microorganisms. J. Anim. Sci. 70:1188-1194

House, W. A., and A. W. Bell. 1993. Mineral accretion in the fetus and adnexa during late gestation in Holstein cows. J. Dairy Sci. 76:2999-3010

Kume, S.-I., and S. Tanabe. 1994. Effect of twinning and supplemental iron-saturated lactoferrin on iron status of newborn calves. J. Dairy Sci. $77: 3118-3123$.

Martinez, A., and D. C. Church. 1970. Effect of various mineral elements on in vitro rumen cellulose digestion. J. Anim. Sci. 31:982-990.

McCaughey, K. M., E. J. DePeters, P. H. Robinson, J. E. P. Santos, S. J. Taylor, and J. W. Pareas. 2005. Impact of feeding whole upland cottonseed, with or without cracked pima cottonseed with increasing addition of iron sulfate, on milk and milk fat composition of lactating dairy cattle. Anim. Feed Sci. Technol. 123-124:667-685.
McGuire, S. O., W. J. Miller, R. P. Gentry, M. W. Neathery, S. Y. Ho, and D. M. Blackmon. 1985. Influence of high dietary iron as ferrous carbonate and ferrous sulfate on iron metabolism in young calves. J. Dairy Sci. 68:2621-2628.

Miltenburg, G. A. J., T. Wensing, J. P. M. van Vliet, G. Schuijt, J. van de Broek, and H. J. Breukink. 1991. Blood hemoglobin, plasma iron, and tissue iron in dams in late gestation, at calving, and in veal calves at delivery and later. J. Dairy Sci. 74:3086-3094.

Miret, S., R. J. Simpson, and A. T. McKie. 2003. Physiology and molecular biology of dietary iron absorption. Annu. Rev. Nutr. 23:283-301.

Miyata, Y., and K. T. Furugouri. 1987. The relationship between serum ferritin concentration and tissue non-heme iron or tissue ferritin in dairy cattle. Jpn. J. Vet. Sci. 49:1157-1159.

NRC. 1989. Nutrient Requirements for Dairy Cattle. 6th rev. ed. ed. Natl. Acad. Press, Washington DC.

NRC. 2001. Nutrient Requirements of Dairy Cattle. 7th rev. ed. ed. Natl. Acad. Press, Washington DC.

Niederman, C. N., D. Blodgett, D. E. Eversole, G. G. Schurig, and C. D. Thatcher. 1994. Effect of copper and iron on neutrophil function and humoral immunity of gestating beef cows. J. Am. Vet. Med. Assoc. 204:1796-1800.

Rao, J., and V. Jagadeesan. 1996. Lipid peroxidation and activities of antioxidant enzymes in iron deficiency and effect of carcinogen feeding. Free Radic. Biol. Med. 21:103-108.

Reece, W. O., P. O. Brackelsberg, and D. K. Hotchkiss. 1985. Erythrocyte changes, serum iron concentration and performance following iron injection in neonatal beef calves. J. Anim. Sci. 61:1387-1394

Reynolds, M. 1953. Measurement of bovine plasma and blood volume during pregnancy and lactation. Am. J. Physiol. 175:118-122.

SAS Institute. 2004. SAS/Stat User's Guide, Version 9. SAS Institute Inc., Cary, NC.

Thomas, J. W., M. Okamoto, W. C. Jacobson, and L. A. Moore. 1954 A study of hemoglobin levels in the blood of young dairy calves and the alleviation of anemia by iron. J. Dairy Sci. 37:805-812.

Underwood, E. J., and N. F. Suttle. 1999. The Mineral Nutrition of Livestock. 3rd ed. CABI Publishing, New York, NY.

van Ravenswaay, R. O., P. R. Henry, and C. B. Ammerman. 2001. Effects of time and dietary iron on tissue iron concentration as an estimate of relative bioavailability of supplemental iron sources for ruminants. Anim. Feed Sci. Technol. 90:185-198.

Weiss, W. P., and J. W. Spears. 2005. Vitamin and trace mineral effects on immune function of ruminants. Pages 473-498 in 10th Int. Symp. Ruminant Physiology. Wageningen Denmark, Copenhagen, Denmark. 